\title{
Correction to: The impact of the COVID-19 pandemic and associated public health response on people with eating disorder symptomatology: an Australian study
}

Jane Miskovic-Wheatley ${ }^{1 *} \mathbb{0}$, Eyza Koreshe ${ }^{1}$, Marcellinus Kim² ${ }^{2}$ Rachel Simeone ${ }^{1}$ and Sarah Maguire ${ }^{1}$

\section{Correction to: Journal of Eating Disorders (2022) 10:9 https://doi.org/10.1186/s40337-021-00527-0}

Following the publication of the original article [1], the authors brought to our attention that an error was unfortunately introduced to Table 3 during the implementation of their corrections by the correction team:
A graphic intended to be included in Table 3, inadvertently replaced the entire Table.

The correct Table 3 is shown here below and has now been included in the original article.

Author details

${ }^{1}$ InsideOut Institute, Central Clinical School, Faculty of Medicine and Health, The University of Sydney, Charles Perkins Centre, Camperdown, NSW 2006, Australia. ${ }^{2}$ Sydney Local Health District, St Leonards, NSW, Australia.

Published online: 14 February 2022

\section{Reference}

1. Miskovic-Wheatley J, et al. The impact of the COVID-19 pandemic and associated public health response on people with eating disorder symptomatology: an Australian study. J Eat Disord. 2022;10:9. https://doi.org/ 10.1186/s40337-021-00527-0.

\section{Publisher's Note}

Springer Nature remains neutral with regard to jurisdictional claims in published maps and institutional affiliations. to the material. If material is not included in the article's Creative Commons licence and your intended use is not permitted by statutory regulation or exceeds the permitted use, you will need to obtain permission directly from the copyright holder. To view a copy of this licence, visit http://creativecommons.org/licenses/by/4.0/. The Creative Commons Public Domain Dedication waiver (http://creativecommons.org/publicdomain/zero/1.0/) applies to the data made available in this article, unless otherwise stated in a credit line to the data. 
Table 3 Pandemic experience and impact on eating disorder index $(N=1723)$

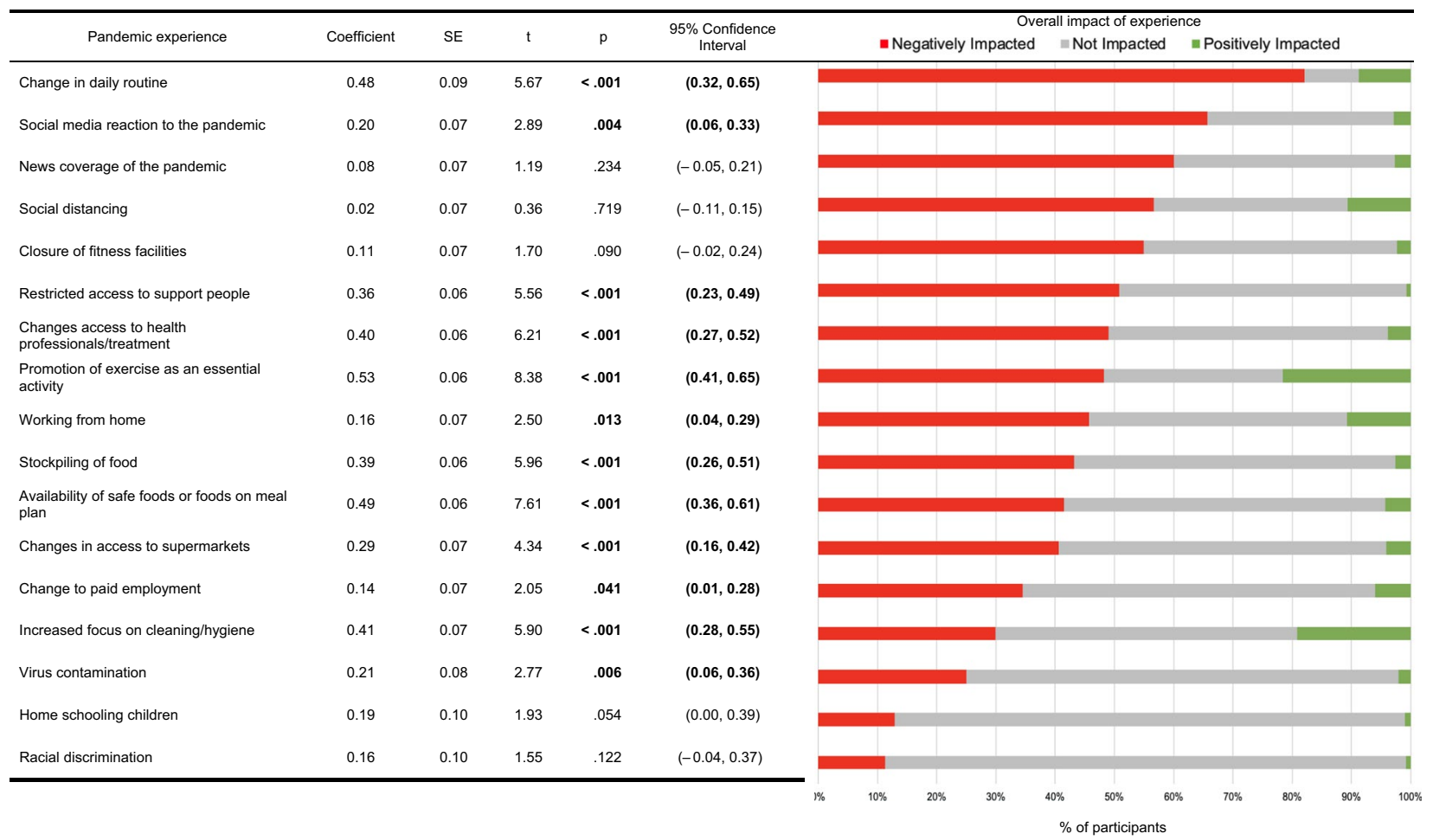

$\mathrm{N}$, sample size; $\mathrm{SE}$, standard error; $\mathrm{Cl}$, confidence interval; $p$, $p$-value significant at $p<.05 ; \mathrm{t}$, $\mathrm{t}$-statistic 